\title{
КОНЦЕПТУАЛЬНІ НАПРЯМИ ФОРМУВАННЯ УПРАВЛІННЯ РЕГІОНАЛЬНИМ МЕДИЧНИМ ЦЕНТРОМ НА ПРИНЦИПАХ ДЕРЖАВНО-ПРИВАТНОГО ПАРТНЕРСТВА
}

\author{
Київська обласна клінічна лікарня, м. Київ, Україна
}

\begin{abstract}
Мета: обґрунтувати концептуальні напрями формування управління регіональним медичним центром на принципах державно-приватного партнерства.

Матеріали і методи. Для досягнення поставленої мети у роботі застосовували загальнонаукові методи аналізу, синтезу, узагальнення, інтерпретації наукових даних, а також системний і структурно-срункціональний підходи.

Результати. Концептуальні напрями фрормування управління регіональним медичним центром спрямовані на вирішення практичного завдання - організації діяльності медичного закладу, який працює на принципах державноприватного партнерства. Вони обґрунтовані з урахуванням системного підходу, Конституції України, законів та інших нормативно-правових актів України, загальновизнаних принципів і норм міжнародного права у галузі охорони здоров'я, вітчизняного і зарубіжного досвіду. Концептуальні напрями фрормують нову систему управління медичним закладом на принципах державно-приватного партнерства, забезпечують стійкий економічний стан і можливість розвитку виробничої бази медичного закладу.

Висновки. Розробка концептуальних напрямів дозволила оптимізувати роботу регіонального медичного центру за рахунок визначення основних принципів формування управління з механізмами державно-приватного партнерства, організації інтегрованої системи управління, створення едективної та результативної системи маркетингу і, як результат, забезпечити задоволеність пацієнтів послугами регіонального медичного центру.
\end{abstract}

КЛЮчОВІ СЛОВА: управління; регіональний медичний центр; державно-приватне партнерство.

У жовтні 2010 р. вступив у силу Закон України «Про державно-приватне партнерство»- закон, який відображає точку зору української держави щодо принципів, фрорм і умов взаємодії бізнесу і держави.

Державно-приватне партнерство (ДПП), як спосіб організації публічно-приватних правовідносин, на практиці реалізується у фрормах спільної діяльності, управління державним майном, оренди державного майна та деяких інших. Термін «державно-приватне партнерство» використовується як політико-управлінська, а не юридична категорія. ДПП визначається як співпраця між державою, в особі її органів, та суб'єктами господарювання, основана на договірній основі $[1,21]$.

Актуальність дослідження зумовлена економічною ситуацією, яка склалася в Україні, відсутністю ефективної та прозорої моделі фрінансування системи медичної допомоги, орієнтованої на реальні потреби пацієнтів, а також появою в Україні законодавчої бази для розвитку ДПП [4-6].

Реалізація механізмів державно-приватного партнерства забезпечує еорективне застосування найважливішого інструменту управління системою охорони здоров'я - планування, акцентом якого стає залучення інвестицій для досягнення цілей закладів охорони здоров'я (303) і надання широкого спектра послуг, доступних для всього населення [3, 7].

Мета дослідження: обґрунтувати концептуальні напрями фрормування управління регіональ-

(c) A. B. Іванюк, 2021 ним медичним центром (РМЦ) на принципах державно-приватного партнерства.

Матеріали і методи. Для досягнення поставленої мети у роботі застосовували загальнонаукові методи аналізу, синтезу, узагальнення, інтерпретації наукових даних, а також системний і структурно-фрункціональний підходи.

Результати дослідження та їх обговорення. На основі аналізу наукових джерел було виявлено, що застосування механізмів ДПП є загальносвітовою тенденцією розвитку системи охорони здоров'я.

Входження приватного капіталу в сфреру охорони здоров'я стало нормою і $\epsilon$ ефективним фрактором впровадження у галузь інноваційних практик лікування і сучасного технологічного оснащення клінік, забезпечення якості медичної допомоги, фрормування цифрової галузі охорони здоров'я. Все це актуалізує розробку концептуальних напрямів фрормування управління регіональним медичним центром на принципах державно-приватного партнерства.

При обґрунтуванні концептуальних напрямів формування управління регіональним медичним центром на принципах ДПП ми виділили 8 основних блоків (рис. 1).

I. Мета і завдання формування і розвитку системи процесно-орієнтованого управління на основі інтегрування бізнес-процесів

Мета - сорормувати управління якісно нового типу, процесно-орієнтоване управління моделлю РМЦ на принципах ДПП, під керуванням - професійних менеджерів. 


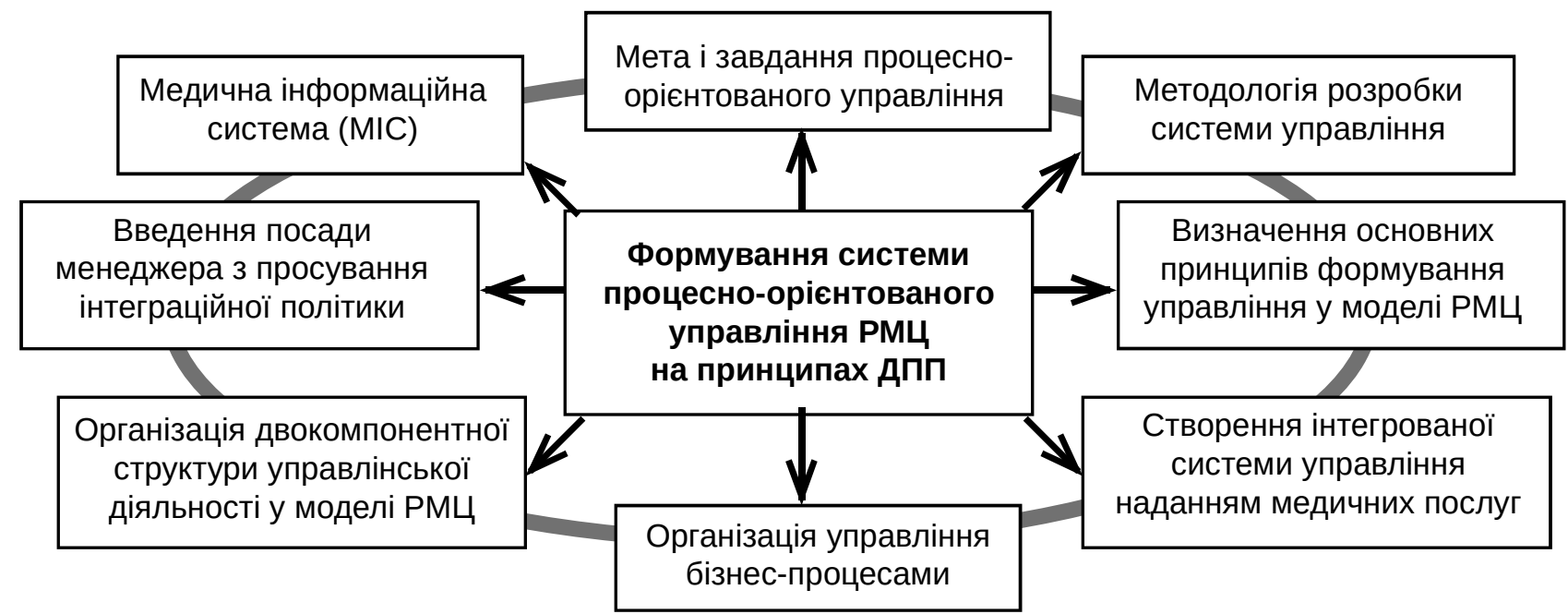

Рuc. 1. Концептуальні напрями формування системи процесно-орієнтованого управління регіональним медичним центром на принципах державно-приватного партнерства.

Завдання:

- забезпечити доступнутависококваліфіковану медичну допомогу населенню регіону;

- забезпечити ефрективну і результативну діяльність РМЦ;

- забезпечити можливість модернізації та диверсифрікації - розширення асортименту послуг, освоєння нових видів послуг із метою підвищення еорективності діяльності та отримання економічної вигоди.

II. Методологія розробки управління бізнеспроцесами у моделі РМЦ

Методологія розробки управління у РМЦ - це програма, набір методів аналізу міжнародного досвіду, основних блоків медичної діяльності, процедур і технології моделювання управління бізнес-процесами у моделі РМЦ. Це стратегія управління РМЦ у нових економічних умовах.

III. Визначення основних принципів формування управління РМЦ на принципах ДПП

При організації сучасної моделі РМЦ на принципах ДПП об'єднуються потенціали держави і приватного бізнесу. Управління РМЦ на принципах ДПП переходить від державного управління до державно-приватної правової фрорми управління.

РМЦ надає комплексну консультативно-діагностичну допомогу пацієнтам з урахуванням нових ффункцій і особливостей моделі.

До основних принципів фрормування управління РМЦ на принципах ДПП можна віднести:

- розробку адміністративно-правового статусу РМЦ на принципах ДПП з державно-приватною фрормою управління, 3 повною юридичною і господарською самостійністю центру;

- повне розділення функцій замовника і виробника. Справедливий розподіл ризиків між партнерами;

- забезпечення багатоканальних джерел фрінансування РМЦ;

- впровадження еорективних методів організації інноваційного процесу, освоєння сучасних технологій, медичного обладнання;
- контроль стандартів медичних послуг, методів їх оплати, процедур управління ресурсами;

- контроль ефрективності виробництва за критеріями прибутку і рентабельності;

- застосування економічної мотивації праці персоналу;

- укомплектування РМЦ висококваліфрікованим медичним персоналом;

- введення механізмів економічної зацікавленості персоналу в підвищенні якості медичної допомоги;

- створення автоматизованих систем управління;

- моніторинг роботи з кадрами;

- моніторинг поточної діяльності 3 аналізом роботи усіх відділень і лікарів;

- прогнозування діяльності РМЦ;

- прогнозування потреб пацієнтів;

- моніторинг задоволеності пацієнтів;

- забезпечення процесно-орієнтованого управління, фрормування сучасних організаційноправових, економічних механізмів управління моделлю.

В основу управління РМЦ закладається принцип процесно-орієнтованого підходу до управління, котрий полягає у тому, що діяльність РМЦ представляє мережу взаємопов'язаних бізнеспроцесів.

Процесно-орієнтоване управління РМЦ передбачає широке делегування повноважень і відповідальності виконавцям, що забезпечує зменшення кількості рівнів прийняття рішень і підвищення уваги до питань забезпечення якості медичних послуг. Цей метод дозволяє оперативно змінювати і допрацьовувати технології, безболісно модернізувати інформаційно-аналітичну систему РМЦ.

IV. Створення інтегрованої системи управління наданням медичних послуг у моделі РМЦ

Вдосконалення системи управління медичними службами в РМЦ забезпечує їх інтеграція на принципах державно-приватного партнерства. 
Інтеграція в РМЦ на принципах державноприватного партнерства вирішує п'ять основних проблем:

- інтеграцію основних медичних служб кардіологічної та кардіохірургічної допомоги, об'єднаних під одним «дахом», що забезпечить надання пацієнту найкращих можливостей лікування, відповідного до світових стандартів;

- інтеграцію між лікувальними і консультативно-діагностичними відділеннями РМЦ, що забезпечує кращу підготовку хворого до госпіталізації;

- інтеграцію у РМЦ двох потоків пацієнтів, споживачів платних і безоплатних медичних послуг, що забезпечує доступність до високотехнологічної кардіологічної допомоги всіх верств населення;

- інтеграцію консультативно-діагностичного відділення РМЦ $з$ кардіологами у районних лікарнях (на договірних умовах), що забезпечить координацію і наступність у лікуванні та загальну націленість на досягнення кінцевого клінічного та економічного результату;

- інтеграцію РМЦ і етапу реабілітації.

Головним економічним інструментом інтеграції у моделі РМЦ є механізм ДПП, який передбачає об'єднання державних і приватних коштів для надання високотехнологічної медичної допомоги населенню регіону.

РМЦ на принципах ДПП - стає фондоутримувачем 3 подальшими розрахунками за послуги з усіма інтегрованими медичними службами, що працюють в кооперації з РМЦ.

V. Організація управління бізнес-процесами

Бізнес-процес - це сукупність взаємопов'язаних заходів або робіт, націлених на створення конкретної послуги для споживачів.

Під бізнес-процесом у РМЦ ми розуміємо сукупність різноманітних видів діяльності, що перетворять рутинні операції і послуги у послуги, які становлять цінність для пацієнта.

Управління бізнес-процесами у РМЦ передбачає виділення 3 усіх процесів тільки тих, які $€$ найбільш пріоритетними 3 економічної точки зору. У зв'язку з тим, усім фрункціонуючим процесам проводиться оцінка співвідношень: ресурси - результат, вхід - вихід.

В управлінні бізнес-процесом виділяється процесний підхід, який наскрізь проходить через всі рівні організації і відповідає за будь-яку певну дію від початку і до кінця. Процесний підхід до організації і управління дозволяє РМЦ отримати такі переваги:

- створюються умови для широкого делегування повноважень і відповідальності виконавцям, що сприяє підвищенню якості послуг і процесів;

- кожен працівник моделі РМЦ прив'язаний до остаточного результату і відповідає за його якість;

- основним критерієм якості та цінності медичної послуги є задоволення потреб споживачів;

- скорочується кількість рівнів прийняття рішень, унаслідок чого підвищується оперативність і адаптивність діяльності РМЦ;
- усуваються невиправдані витрати, які не впливають на процес створення цінності медичних послуг;

- покращуються комунікації, оскільки обмін інформацією здійснюється усередині робочої групи бізнес-процесу, що виключає її спотворення, а також значно скорочує терміни передачі інорормації від одного суб'єкта бізнес-процесу до іншого;

- створюються умови для автоматизації технологій виконання бізнес-процесів у моделі.

Впровадження сучасної моделі управління бізнес-процесами у РМЦ дозволить їй показати на ринку медичних послуг всі свої переваги, які конкретний пацієнт може перевірити. Займатися впровадженням системи управління повинен один із заступників головного лікаря, маркетолог або посадова особа, яка володіє необхідним набором управлінських і розпорядчих функцій.

Таким чином, у РМЦ на зміну фрункціональному управлінню приходить процесно-орієнтований підхід, що представляє управління бізнес-процесами як сукупністю видів діяльності, які мають цінність для споживача.

VI. Організація двокомпонентної структури управлінської діяльності у РМЦ

При побудові організаційної структури управління РМЦ повинні враховувати ключові принципи менеджменту: ієрархічність, подільність, комплексність, а також замкнутість управлінського циклу. Тому структура управління повинна певним чином впливати на всі бізнес-процеси моделі зі застосуванням ефективних прийомів і методів. Діяльність РМЦ схематично являє собою двокомпонентну структуру, яка наведена на рисунку 2.

Управління у РМЦ повинно мати ефективну систему маркетингу та моніторингу задоволеності пацієнтів. У маркетингу медичних послуг особливу увагу приділяють взаємодії РМЦ і пацієнта. Пацієнт залучений до безперервного циклу створення та споживання послуг, а медпрацівник повинен розуміти, яку медичну послугу йому краще запропонувати. Імовірність повторного звернення пацієнта до РМЦ часто залежить саме від того, які стосунки з медичними працівниками у нього складуться. Ефрективність маркетингу впливає на вибір пацієнта. Тому повинні визначати ті показники, за якими потенційній пацієнт обирає РМЦ.

VII. Введення менеджера $з$ просування інтеграційної політики

Визначати інтеграційну стратегію і здійснювати загальне управління цим напрямом повинен один 3 керівників вищої ланки - заступник генерального директора РМЦ. У його обов'язки увійде керівництво проектами інтеграції: окремих медичних служб; лікувальних відділень і консультативно-діагностичного відділення РМЦ; двох потоків пацієнтів - комерційних (платних) і соціальних (безкоштовних, пільгових); регіональних лікарів і РМЦ; РМЦ і представників етапу реабілітації.

VIII. Впровадження медичної інформаційної системи 


\section{Управлінська діяльність \\ Діяльність, яка представляє цінність для споживача \\ Діяльність, яка додає вартості послугам}

PUс 2. Двокомпонентна структура управлінської діяльності РМЦ на принципах ДПП.

Медична інорормаційна система - це система автоматизації документообігу для медичних закладів, у якій будуть об'єднані системи підтримки прийняття лікарських рішень, електронні медичні картки пацієнтів, дані медичних досліджень у циорровій формі, дані моніторингу стану пацієнтів та багато іншого.

\section{Висновки}

При фрормуванні концептуальних напрямів управління РМЦ на принципах ДПП було виділено вісім блоків, які представляють методику концептуального розвитку системи сучасного управління медичних закладів.
Це дозволило оптимізувати роботу РМЦ за рахунок визначення основних принципів фрормування управління, організації управління бізнес-процесами, створення інтегрованої системи управління, ефрективної та результативної системи маркетингу і, як результат, забезпечити задоволеність пацієнтів послугами РМЦ.

Перспективи подальших досліджень полягають у використанні отриманих результатів для обґрунтування концептуальної моделі організації медичної допомоги на принципах ДПП для регіонального рівня.

\section{Список літератури}

1. Вовк С. М. Інституційні десрініції розуміння державно-приватного партнерства в медицині / С. М. Вовк // Держава та регіони. - 2016. - № 3 (55). - С. 23-27. - (Серія «Державне управління»).

2. Дергачова В. В. Державно-приватне партнерство як інституціональний інструмент інвестування економіки країни [Електронний ресурс] / В. В. Дергачова, К. О. Кузнєцова // Бізнес Інформ. - 2018. - № 1. - С. 111-116. - Режим доступу : http://nbuv.gov.ua/UJRN/binf_2018_1_18.

3. Про внесення змін до деяких законодавчих актів України щодо удосконалення законодавства з питань діяльності закладів охорони здоров'я : Закон України від 06.04.2017 р. № 2002-VIII [Електронний ресурс]. - Режим доступу : https://zakon.rada.gov.ua/laws/show/2002-19\#Text.

4. Про внесення змін до деяких законів України щодо усунення регуляторних бар'єрів для розвитку державноприватного партнерства та стимулювання інвестицій в Україні : Закон України від 24.11.2015 р. № 817-VIII [Електронний ресурс]. - Режим доступу : https://zakon.rada. gov.ua/ laws/show/817-19.\#Text.

5. Про державно-приватне партнерство : Закон України із змінами, внесеними згідно із Законами ВВР від 21.06.2012 р. № 5007-VI (5007-17), від 16.10.2012 р. № 5463-VI [Електронний ресурс] // Відомості Верховної Ради України. - 2010. - № 40. - Ст. 524. - Режим доступу : https://zakon.rada.gov.ua/laws/show/2404-17\#Text.

6. Роднянский Д. В. Государственно-частное партнерство в сфере здравоохранения: региональный анализ / Д. В. Роднянский // Международный журнал прикладных наук и технологий «Integral». - 2019. - № 1. - C. $133-139$. 7. Сімак С. В. Особливості методології дослідження державного управління публічно-приватним партнерством на сучасному етапі розвитку України / С. В. Сімак // Інвестиції: практика та досвід. - 2016. - № 5. - С. $88-92$.

\section{References}

1. Vovk, S.M. (2016). Institutsiyni definitsiyi rozuminnya derzhavno-pryvatnoho partnerstva v medytsyni. [Institutional definitions of understanding public-private partnership in medicine]. Derzhava ta rehiony. Seriya: Derzhavne upravlinnya. State and Regions. Series: Public Administration, 3 (55), 23-27 [in Ukrainian].

2. Derhachova, V.V. \& Kuznyetsova, K.O. (2018). Derzhavno-chastnoe partnerstvo yak institutsional'niy instrument investuvannya ekonomiky krayiny [Public-private partnership as an institutional tool for investing in the country's economy]. Biznes Inform. - Business Inform., 1, 111-116 [in Ukrainian].

3. (2017). Zakon Ukrayiny vid 06.04.2017 № 2002 VIII «Pro vnesennya zmin do deyaky zakonodavcho AKTIV Ukrayiny otnosytelno udoskonalennya zakonodavstva po voprosam DIYALNOSTI zakladiv okhorony zdorovya». [Law of Ukraine of 06.04.2017 No. 2002-VIII "On Amendments to Certain Legislative Acts of Ukraine on Improving Legislation on the Activities of Health Care Institutions"]. -zakon.rada.gov.ua. - Retrieved from: https://zakon.rada.gov.ua/laws/show/2002-19\#Text [in Ukrainian].

4. (2015). Zakon Ukrayiny vid 24.11.2015 № 817-VIII «Pro vnesennya zmin do deyaky Zakoniv Ukrayiny otnosytelno Usunennya rehulyatornykh baryeriv dlya rozvytku derzhavno-pryvatnoho partnerstva ta stymulyuvannya investitsiy $v$ Ukrayini» [Law of Ukraine of 24.11.2015 No. 817-VIII "On Amendments to Certain Laws of Ukraine on Elimination of Regulatory Barriers to the Development of Public-Private Partnerships and Stimulation of Investments in Ukraine"]. zakon.rada.gov.ua. - Retrived from: https://zakon.rada.gov.ua/laws/show/817-19.\#Text [in Ukrainian].

5. (2012). Zakon Ukrayiny Pro derzhavno-pryvatne partnerstvo Vidomosti Verkhovnoyi Rady Ukrayiny (VVR), 2010, № 40, st.524. Iz zminami, vnesenymy sohlasno iz Zakonamy VVR N 5007-VI (5007-17) vid 21.06.2012, 16.10.2012. [Law of Ukraine On Public-Private Partnership Vidomosti Verkhovnoi Rady Ukrainy (VVR), 2010, No. 40, p.524. With changes made in accordance with the Laws of the Supreme Administrative Court No. 5007-VI (5007-17) of June 21, 2012, October 16, 2012]. - zakon.rada.gov.ua. - Retrived from: https://zakon.rada.gov.ua/laws/show/2404-17\#Text [in Ukrainian]. 
6. Rodnyanskyy, D.V. (2019). Derzhavno-pryvatne partnerstvo v sferi okhorony zdorov'ya: rehional'nyy analiz [Publicprivate partnership in health care: regional analysis]. Mizhnarodnyy zhurnal prykladnykh nauk $i$ tekhnolohiy «Integral» International Journal of Applied Sciences and Technologies „Integral”, 1, 133-139 [in Russian].

7. Simak, S.V. (2016). Osoblyvosti Metodolohiyi doslidzhennya derzhavnoho upravlinnya publichno-pryvatnym partnerstvom na suchasnosty etapi rozvytku Ukrayiny [Peculiarities of the methodology of public administration research by publicprivate partnership at the current stage of development of Ukraine]. Investytsiyi: praktyka ta dosvid. - Investments: Practice and Experience, 5, 88-92 [in Ukrainian].

\section{CONCEPTUAL DIRECTIONS FOR FORMING THE MANAGEMENT OF THE REGIONAL MEDICAL CENTER ON THE PRINCIPLES OF PRIVATE-PUBLIC PARTNERSHIP}

A. V. Ivanyuk

Kiev Regional Clinical Hospital, Kyiv, Ukraine

Purpose: to substantiate the conceptual directions of forming the management of a regional medical center (RMC) on private-public principles (PPP).

Materials and Methods. To achieve this goal, general scientific methods of analysis, synthesis, generalization, interpretation of scientific data, as well as systemic and structural-functional approaches were used in the work.

Results. The developed conceptual directions for the formation of the RMC management are aimed at solving a practical problem - organizing the activities of a medical facility operating on the principles of PPP. They are substantiated taking into account the systematic approach, the Ukrainian Constitution, laws and other normative legal acts of Ukraine, domestic and foreign experience. Conceptual directions are represented by 8 main blocks. Among them are the goal and objectives of the RMC management forming, the methodology for the management development, the basic principles of the management formation, the organization of integrated management, the management of business processes in the RMC, the introduction of a two-component structure of management, management and a medical information system.

Conclusions. The development of conceptual directions for the RMC management made it possible to optimize the work of the RMC by defining modern principles of management formation, organizing business process management, creating an integrated management system, an effective and efficient marketing system and, as a result, ensuring patient satisfaction with the RMC services.

KEY WORDS: management; regional medical center; public-private partnership.

Відомості про автора:

Рукопис надійшов до редакції 29.04.2021 p.

Іванюк Анатолій Вікторович - кандидат медичних наук, завідувач Центру кардіохірургії Київської обласної клінічної лікарні; тел. +38(044) 237-02-86. 